\title{
Guinea-Pig Adipose Tissue Responsiveness to Catecholamines
}

We were prompted to determine whether guinea-pig epididymal fat pads would respond to the lipolytic effects of selected catecholamines under our conditions of test in view of the observations of RUDMAN ${ }^{1}$ and of RUDMAN and SHANK ${ }^{2}$ that this tissue was insensitive to epinephrine and to norepinephrine.

Methods. The procedure was that described earlier for rats ${ }^{3,4}$ using finely minced guinea-pig fat pads except that the incubations were continued over a $3 \mathrm{~h}$ period in place of the $1 \frac{1}{2} \mathrm{~h}$ period of the rat test. Samples for glycerol determinations were accordingly taken at $11 / 2$ and $3 \mathrm{~h}$ in place of the $1 / 2$ and $1 \mathrm{~h}$ samplings of the procedure described earlier.

Results and discussion. The lipolytic activities of some selected catecholamines on the basis of 4 or 5 multiplelevel paired tests are summarized graphically in the Figure. The relative activities were determined by least squares calculation on the basis of the individually determined values.

The relative activities are shown in the Table to be close to those found for rat epididymal tissue under our conditions of test. Guinea-pig tissue, however, is less responsive in that a $3 \mathrm{~h}$ incubation period was used for these determinations in place of the $1 \mathrm{~h}$ period of the rat test.
While these studies were in progress reports appeared ${ }^{5,6}$ showing that guinea-pig adipose tissue responds lipolytically to epinephrine and to norepinephrine in accord with the findings given above. Thus, it is possible that the reduced responsiveness of guinea-pig adipose tissue may have misled Rudman ef al, ${ }^{1,2}$ since, under their conditions of test, tissue slices in an albumin-free medium could not elicit the positive effect they had noted with rat and hamster adipose tissue slices. We are less inclined to believe that the difference in results can be ascribed to the tissue preparations used, that is, minces or slices.

These findings with guinea-pig tissue lend additional support to the suggestion made earlier ${ }^{7,8}$ that the adrenergic receptor for adipose tissue corresponds in responsiveness to the cardiac receptors but differs from the receptors for vasodepression and for dilation of guinea-pig bronchioles. Thus it may be seen from the comparisons of the Table, while the concordance for the lipolytic responsiveness for guinea-pig and for rat adipose tissues is good $(r=0.98, \log : \log$ comparison $)$, that for guinea-pig adipose tissue and guinea-pig bronchioles is clearly different $(r=0.02, \log : \log$ comparison).

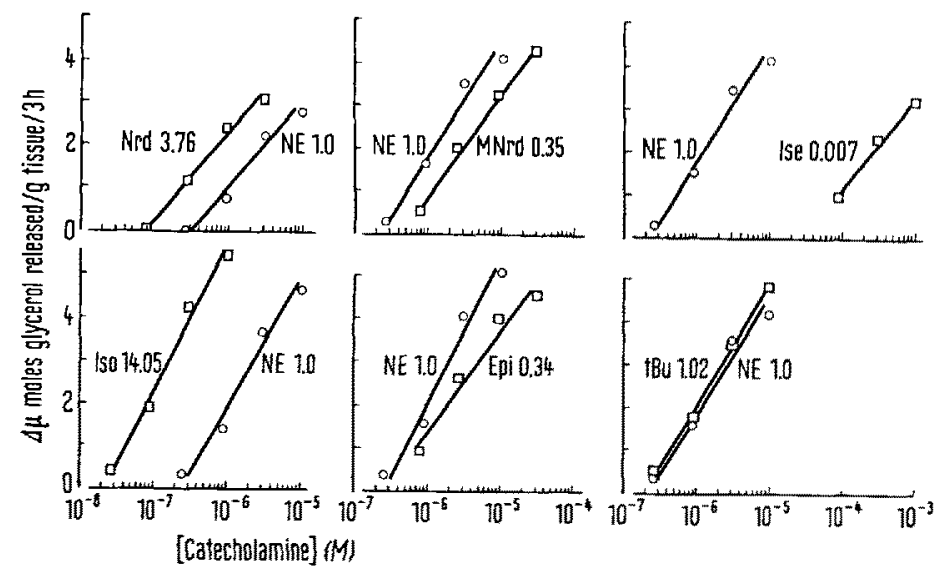

Guinea-pig adipose tissue lipolytic responsiveness to L-nordefrine (Nrd), DL- $N$-methyl- $\alpha$-methyl-norepinephrine (MNrd), bu-isoetharine (Ise), L-isoproterenol (Iso), epinephrine (Epi) and to $D L-N$-t-butyl-norepinephrine in comparison with that to $\mathrm{L}$-norepinephrine in multiple-level tests. The points are based on 4 or 5 paired tests.
Relative responsiveness of guinea-pig fat pads, rat fat pads and guinea-pig bronchioles to catecholamines

\begin{tabular}{|c|c|c|c|}
\hline \multirow[t]{2}{*}{ Catecholamines } & \multicolumn{2}{|c|}{ Lipolytic activity } & \multirow{2}{*}{$\begin{array}{l}\text { Guinea-pig } \\
\text { broncho- } \\
\text { dilator } \\
\text { activityb }\end{array}$} \\
\hline & Guinea-pig & Rat & \\
\hline $\begin{array}{l}\text { L-Isoproterenol } \\
\left.\text { (bitartrate } \cdot 2 \mathrm{H}_{2} \mathrm{O}\right)\end{array}$ & 14.05 & 11.7 & 1000 \\
\hline $\begin{array}{l}\text { L-Norepinephrine } \\
\text { (bitartrate } \cdot \mathrm{H}_{2} \mathrm{O} \text { ) }\end{array}$ & 1.0 & 1.0 & 3 \\
\hline Epinephrine (bitartrate) & 0.34 & 0.72 & 230 \\
\hline L-Nordefrine (mucate) & 3.76 & 1.67 & 7 \\
\hline $\begin{array}{l}\text { DL- } N \text {-Methyl- } \alpha \text {-methyl- } \\
\text { norepinephrine (HCl) }\end{array}$ & 0.35 & 0.53 & 120 \\
\hline $\begin{array}{l}\text { DL- } N \text {-t-Butyl-norepinephrine } \\
\text { (acetate) }\end{array}$ & 1,02 & 1.04 & 1075 \\
\hline DL-Isoetharine $(\mathrm{HCl})$ & 0.007 & 0.051 & 115 \\
\hline
\end{tabular}

Data of ARnold and McAulifF ${ }^{4}$, data of LANDs et al. ${ }^{a}$.
Zusammenfassung. Es wurde festgestellt, dass Meerschweinchen-Fettgewebe auf Catecholamine weniger reagierte als Rattengewebe. War die Inkubation zerkleinerten Gewebes mit Aminen langfristig, so zeigte das Meerschweinchen-Fettgewebe eine lipolytische Aktivität.

\section{A. Arnold and J. P. McAuliff}

Sterling-Winthrop Research Institute, Rensselaer, (New York 12144, USA), 13 November 1967.

1 D. Rudman, J. Lipid Res. 4, 119 (1963).

2 D. RudMan and P. W. SHANK, Endocrinology 79, 565 (1966).

3 M. ĈRnohorsky, J. ĆEPELIK, D. Lincová and M. Wenke, J. Pharm. Pharmac. 18, 188 (1966).

4 A. ARnold and J. P. McAuliff, Biochem. Pharmac., in press.

5 E. Zakaria and E. Shafrir, Proc. Soc. exp. Biol. Med. 124, 1265 (1967).

- R. Mater, L. Maitre and M. Staeielin, Biochem. Pharmac. 16, 597 (1967).

2 A. Arnold, J. P. McAuliff, F. P. Luduena, T. G. Brown JR. and A. M. LANDs, Fedn Proc. Fedn Am. Socs exp. Biol. 25, 500 (1966).

A A. M. Lands, A. Arnold, J. P. Mcauliff, F. P. Luduena and T. G. Brown JR., Nature 214, 597 (1967). 